\title{
Approximation of Nautical Tourism Routes by Applying the Markov Chain
}

\author{
Ines KOLANOVIĆ, Nela JADRIJEVIĆ, Tanja POLETAN JUGOVIĆ
}

\begin{abstract}
Nautical tourist routes and ports of nautical tourism referred to as points of transits for sports and leisure crafts form a unique system within the nautical tourist offers are defined. Nautical traffic functions according to specific regularities that have to be continuously studied and analysed in order to eliminate bottlenecks that represent the main obstacles for offering high quality services. Therefore, the purpose and aim of this research has been the approximation of nautical tourist routes for ports of nautical tourism within the Istarska and Primorsko-goranska County in the Republic of Croatia by applying the Markov chain method. Taking into consideration specific regularities in the formation of nautical tourist routes within the ports of nautical tourism, fourteen state systems have been analysed, two of which relate to those nautical tourist routes that pass across Italy and Slovenia when crafts have to enter or leave the ports. The results of this research have revealed bottlenecks areas within nautical tourism ports and their related routes that have been formed within the Istarska and Primorsko-goranska County.
\end{abstract}

Key words: bottlenecks; Markov chain; nautical tourist routes; ports of nautical tourism; stochastic system

\section{INTRODUCTION}

For the purpose of modeling nautical tourism routes for sports and leisure formed between nautical tourism ports, this research uses the Markov chain model. It is a useful mathematical model in the context of study of the nature of movement of certain subjects from one location to another or the movement of the observed subject from one state to another. [1]

At the same time, Markov chain enables forecasting of future patterns of craft movement, assuming that the observed pattern of craft movement is unobstructed. External factors such as the construction of new nautical tourism ports and the enhancement of the competitiveness of some nautical tourism ports affect the changes of the observed pattern of craft movement. [2]

By analyzing previous research works, it was found that Markov chain has been used by authors in researches related to modeling of traffic and the approximation of bottlenecks on traffic flows in stochastic systems.

Mladineo, N. et al. in the paper on "Decision Support System for the Development of Yachting in the Adriatic Sea", use Markov chain to design the frequency matrix of crafts entering 26 ports that make up the nautical tourism system called by the authors System of yachting tourism (SYT) [3]. In addition, Hazelton M. L. and David P. W. in their paper "Computation of equilibrium distributions of Markov traffic-assignment models" use Markov chain in traffic modeling, observing the interaction between the formation of bottlenecks in traffic and the pieces of information collected from drivers, which on their part influence the selection by the drivers [4]. Hu, J. and Prandini, M. in the paper "Aircraft conflict detection: a method for computing the probability of conflict based on Markov chain approximation" use Markov chain in approximating stochastic processes describing the relative positions of airplanes in the air traffic for the purpose of exploring the problem of automated detection of possible collision between two aircrafts and the probability of collision of two aircrafts at a certain height [5].

The Markov chain model has been applied with the aim of approximating the nautical tourism routes at the system level, by establishing a matrix of transition values, that determines the probability of transition (entering/ leaving) of sports and leisure crafts (up to 20 meters) between the nautical tourism ports, and the calculation of the stationary distribution vector. The system is identical to the nautical tourism ports network for the nautical traffic to take place, and it comes to balance where the average number of sports and leisure crafts entering a given nautical tourism port equals the average number of crafts leaving that port over a given period. The status of the system in operation includes some nautical tourism ports located respectively in the Istarska and the Primorskogoranska Counties in the Republic of Croatia.

According to the defined research purpose and target, the basic hypothesis of the research in this paper is: Using the Markov chain method, patterns of craft motion can be analyzed and determined whereupon the areas can be detected of bottleneck formation within the network of routes between nautical tourism ports.

The conducted research has resulted in the detection of bottleneck formation areas within the system of nautical tourism ports and nautical tourism routes that are formed by crossings of sports and leisure crafts in the Istarska and the Primorsko-goranska Counties.

\section{THEORETICAL POSTULATES OF MARKOV CHAIN IN THE FUNCTION OF THE NAUTICAL TOURISM ROUTE MODELING}

The Markov chain can be defined as a specific form of a stochastic process whereby it is possible to determine the likelihood of possible future outcomes that depend on the present state rather than on the history of the process or the way that has lead to the present state. [1]

In this paper, the transition probabilities are determined of a craft entering a certain nautical tourism port from a previous nautical tourism port. In most cases, the exact value of these real fixed basic probabilities is unknown and the value of the movement probability should be assumed or estimated for most sailing directions. [1] It is therefore important for the value of the probability that a particular nautical tourism port will be visited to be estimated as accurately as possible.

The value of the transition probability $p_{i j}$ indicates the probability for the process to be moving from state $S_{i}$ to state $S_{j}$ for each pair of states. The probability set or the 
outcome function describes the movement of the process through any finite number of steps. The probability of a craft crossing from one nautical tourism port to another can be shown in the form of the transition matrix $P$. The matrix $P$ elements denote the probability of movement from state $S_{i}$ to state $S_{j}$ in the next step. Since matrix elements must not be negative and the sum of elements in each line equals 1 , each line is called the probability vector, and the matrix $P$ is a stochastic matrix. [1]

$$
\boldsymbol{P}=\begin{array}{cccccc} 
& S_{1} & S_{2} & S_{3} & \cdots & S_{n} \\
S_{1} & p_{11} & p_{12} & p_{13} & \cdots & p_{1 n} \\
S_{2} & p_{21} & p_{22} & p_{23} & \cdots & p_{2 n} \\
\vdots & \vdots & \vdots & \vdots & \cdots & \vdots \\
S_{n} & p_{n 1} & p_{n 2} & p_{n 3} & \cdots & p_{n n}
\end{array}
$$

where $\sum_{j=1}^{n} p_{i j}=1$

and

$$
\begin{aligned}
& p_{i j} \geq 0 \text { for all } i \text { and } j \\
& \text { Figure } 1 \text { The transition matrix [1] }
\end{aligned}
$$

Where a craft is in state $i$, the probability for the same to be found in state $j$ in the Markov chain next step $n+1$ is indicated by probability $p_{i j}$. [2,] Markov chains are stochastic processes and the processing of collected data yields results that are reflected in probabilities of possible future outcomes. In deterministic models, state $x$ is always joined by state $y$, while in stochastic models, state $x$ is joined by state $y$ with the probability $p$ and by state $z$ with the probability $q=1-p$. [1] The degree of dependence represents the Markov model feature. In the Markov chain, the state system changes by some probability law within time $t$ in such a way that the system changing from the given state $S_{i}$ within time $t_{0+1}$ only depends on state $S_{i}$ within time $t_{0}$ and is independent of system states preceding time $t_{0}$. [1] The Markov feature is manifested in elements of the transition matrix $p_{i j}$ that shows the probability of craft's transition from one nautical tourism port $S_{i}$ to another $S_{j}$ which does not affect the past of the process. The nautical tourism port that was previously visited has no impact on the future as long as the data are known concerning the nautical tourism port where the craft is at the present moment [6].

In the mathematical context, the Markov feature is assumed that requires the following:

$$
\begin{aligned}
& P\left(X_{n+1}=j \mid X_{n}=i, X_{n-1}=i_{n-1}, \ldots, X_{0}=i_{0}\right)= \\
& =P\left(X_{n+1}=j \mid X_{n}=i\right)=p_{i j}
\end{aligned}
$$

for any steps $n$, any states $i, j \in S$ and any possible sets $i_{0}$, $\ldots, i_{n-1}$ of previous states. [7]

It is obvious from the above (2) that the most important information for the process being modeled by the Markov chain modeling is its current state $X_{n}$, while the $X_{n-1}$ and $X_{0}$ variables as past process indicators are neglected since having no impact on the future state $X_{n+1}$ [2].

According to Bertsekas and Tsitsiklis, the probability of the next state $X_{n+1}$ depends on the past only through the value of the present state $X_{n}$. [7] The data collected on $X_{n-1}$ $\ldots X_{0}$, indicating the ports visited by the crafts prior to their arrival at the actual ports, represent the surplus data provided that the data are known on variable $X_{n}=i$ which provides information on the port currently visited by the craft.

\section{MODELING OF CRAFT MOVEMENTS BETWEEN NAUTICAL TOURISM PORTS USING MARKOV CHAIN IN SEVERAL STEPS}

As a stochastic model, Markov chain includes a random craft crossing analysis between nautical tourism ports using the probability theory and mathematical matrix operations. Markov chain is used to model boat crossings between nautical tourism ports in $n$ steps, so that every step of the process only allows for one state of the model. The state is the system of nautical ports being visited by the craft at any time, whereby crafts may either move between different states or may return to the same state in the next step of the process. Where matrix is used, the matrix elements are the probabilities of craft movement between the system states, where the sum of probabilities of craft's leaving a nautical tourism port equals one. [2]

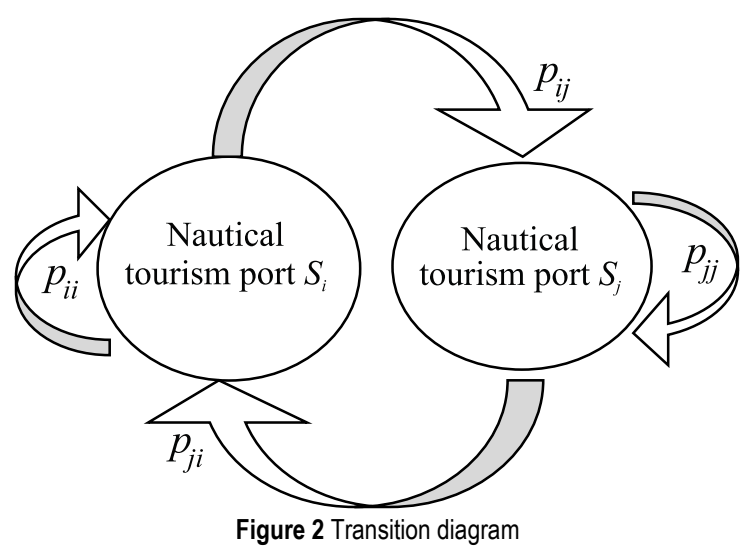

Fig. 2 shows a simple transition diagram describing a possible craft movement between two nautical tourism ports. It is obvious that the simple transition diagram only consists of two states $S_{i}$ and $S_{j}$ that make up the observed stochastic system with associated routes of craft movement and the probabilities of transition for each of the possible trajectories. Fig. 2 clearly shows that if the craft is presently in the $S_{i}$ state, in the next step the craft may either remain in the same state $S_{j}$ with the probability $p_{i i}$ or it may move to the system state $S_{j}$ with the probability $p_{i j}$. Consequently, if the boater decides to go to state $S_{j}$ in the next step, then in the following step of the process he can choose the $p_{j i}$ route which indicates the probability that the craft will move to the initial state $S_{i}$, or the boater can decide to remain in state $S_{j}$, which is evaluated by $p_{j j}$. [2]

In a longer period of operation of the Markov chain in modeling craft's random movement between numbers of nautical tourism ports, the state of the system as it is ceases to depend on its initial state. Thus, the accidental craft movement between nautical tourism ports in a large number of process steps $n$ causes the data to be erased which could be read from the vector of initial distribution. [2]

Many problems that are being addressed by Markov chain require a law of probability based calculation for the state in some future time that is conditioned by the current 
state. The probability law is determined in $n$ steps of transition probability and this is defined as: [7]

$$
r_{i j}(n)=P\left(X_{n}=j \mid X_{0}=i\right)
$$

where $r_{i j}(n)$ stands for the probability that the state after $n$ steps will be $j$, given the current state $i$.

Each $r_{i j}(n)$ converges to some restriction, such as $n \rightarrow$ $\infty$, and this restriction does not depend on the initial state $i$. Now, each state has a positive "stationary" probability of occupancy way far in the future. Furthermore, the probability $r_{i j}(n)$ depends on the initial state $i$ where $n$ equals a small number, yet with time the dependence decreases. Many (but not all) probability models that are developed over time are of a nature that after a long enough time, the effect of their initial state becomes insignificant. [7]

For each state $j$, the $n$-step of transition probability $r_{i j}(n)$ approaches the limit value that is independent of $i$, provided there is no reversibility and no periodicity in the chain. The limit value, designated $\pi j$, is interpreted as [7]

$\pi j \approx P\left(X_{n}=j\right)$

where $n$ equals a large number and represents the stationary probability of $j$.

The above formulas describe the characteristics of crafts'crossings within the network of nautical ports observed in a long period. Thus, the probability of craft movement from the system state $S_{i}$ (a nautical tourism port) to state $S_{j}$, after $n$ steps within the process, tends to the stationary value of $\pi j$. After a large number of crossings between ports made by boats within the nautical ports system network, it becomes unimportant from where the boats had initially set sail, and the system does not depend on the initial distribution. In this support is the fact that the observed system of craft movement within the network of nautical tourism ports is characterized by a class of reciprocating states. Thus, crafts from any nautical tourism ports can enter any other nautical tourism port within the observed system. The balance in the context of maritime transport refers to the distribution of the average number of crafts entering nautical tourism ports which is equal to the average number of crafts leaving that port. [2]

Considering that the system of nautical tourism ports is observed on a long-term basis, which means that the process takes place in a large number of steps $n$, all nautical tourism ports are ports of return and there are no transit ports for nautical tourism within the observed system. Thus, each nautical tourism port is in the function of the reciprocating $S i$ state of the system, meaning that no matter where the craft moves to within the nautical tourism ports, there is a possibility of returning to the system state $\mathrm{Si}$. Where nautical tourism ports are ports of transit, then there is no returning to that port, but there is only the possibility of switching to another state of the system from which there is no return. Thus, at some point, crafts sail out of transit ports and stay forever in the return states of the system. In systems with transit states and multiple classes of returning states, initial states have an impact on the longterm behavior of the system. Given that the subject of research is a set of nautical tourism ports states and crafts accidentally moving between these states, thus creating a communication network, there is only one class of return states. This statement is of utmost importance because according to the Markov chain rule the initial state of the system does not affect the long-term behavior of the system.

In this research, a long-term system modeling is performed and, based on the initial state of the system, probabilities are determined of entering a particular state of the system after a number of system steps $n$. Within the context of the terminology concerned, the long-term modeling refers to the determination of patterns of craft movement between nautical tourism ports, which are in the function of the system state. Every single step $n$ of the system involves one crossing of crafts between two nautical tourism ports. The greater is the number $n$, the greater the rate of crafts entering nautical tourism ports. After a number of crafts entering nautical tourism ports, the system enters the state of balance and redistribution is achieved of crafts among all nautical tourism ports. [2]

\section{APPROXIMATION OF NAUTICAL TOURISM ROUTES FOLLOWING THE EXAMPLE OF NAUTICAL TOURISM PORTS WITHIN THE ISTARSKA AND THE PRIMORSKO- GORANSKA COUNTIES}

The approximation of nautical tourism routes has been carried out at the system level by designing a transition matrix and stationary distributions using the Markov chain method. For the purpose of applying the methodology of approximation of nautical tourism routes, data have been collected on movement of sports and leisure crafts (up to 20 meters) within the network of nautical tourism ports in the Istarska and the Primorsko-goranska Counties in the nautical seasons 2013, 2014 and 2015. [8] Based on the collected data, conclusions and insights were obtained on the characteristics of nautical tourism flows between nautical tourism ports by creating a matrix of transition probabilities. Using the method of survey of nautical visitors in nautical tourism ports, data were collected on crafts' crossings within the nautical tourism ports network. The survey also included skippers directly involved by profession in providing skipper services. The data were collected through emailing on craft positions and from websites (MarineTraffic, Craftfinder, Crafttracker) and mobile application CraftFinder.

Nautical tourism ports represent 14 states of the model, with each element of the transition matrix being transition probabilities. The transition matrix describes the probability of a craft movement from a nautical tourism port (state) to any other nautical tourism port (state). The model has operated on the assumption of the unchanged total number of crafts moving between 14 nautical tourism ports with two arrivals/departures from the Croatian ports network across Italy and Slovenia.

Tab. 1 shows all the $S$ marks with their respective ordinary number and the name of the nautical tourism port the marking refers to. The respective nautical tourism ports are displayed by their geographic position, north to south. Thus, the higher the ordinary number, the system moves towards the south. 


Table 1 System states $[2,9]$
\begin{tabular}{|l|l|}
\hline S1 & Italija \\
\hline S2 & Slovenija \\
\hline S3 & Aci Umag \\
\hline S4 & Marina Nautica \\
\hline S5 & Marina Poreč \\
\hline S6 & Marina Vrsar \\
\hline S7 & Aci Rovinj \\
\hline S8 & Aci Pula \\
\hline S9 & Aci Opatija \\
\hline S10 & Marina Punat \\
\hline S11 & Aci Cres \\
\hline S12 & Aci Supetarska Draga \\
\hline S13 & Y/C Mali Lošinj \\
\hline S14 & Aci Rab \\
\hline
\end{tabular}

In Tab. 1 , the system states respecting $3 \leq$ and $\geq 8$ correspond to the nautical tourism ports geographically located in the area of the Istarska County. [10] All the system states $S_{i}$ respecting $9 \leq$ and $\geq 14$ are geographically related to the Primorsko-goranska County. A more intense traffic communication is clearly evident of the IstarskaCounty with Italy and Slovenia than the traffic communication with the Primorsko-goranska County. The Istria coastline being not as well indented as in other counties, boating in the Istria County area is performed mainly along the coast. Given that the coast is more indented in the Primorsko-goranskaCounty, traffic communication operates between the coastal and island nautical tourism ports. Obviously, the Primorsko-goranska County traffic communication with the IstarskaCounty goes via ACI Pula (S8), Marina Punat (S10), ACI Cres (S11) and Y/C Mali Lošinj (S13). [2]

The transition matrix in Table 2 refers to the transition probabilities that occurred in one step of the process. In other words, the transition probabilities of nautical crafts for one single call at a nautical tourism port are displayed. Looking at the process of craft crossings between nautical tourism ports through a number of steps $n$ within the process, involving a greater number of nautical tourism ports callings at the system level, there are different ways of getting the system into the final state or final nautical tourism port. With the transition probabilities of a craft observed in the long run, the accidental moving of crafts over a long period causes the influence of the initial state of the system to become insignificant. The transition probabilities, after a sufficiently long period of movement between nautical tourism ports, converge to a certain limit value that takes the same value in each column of the transition matrix, thus resulting in a vector representing the stationary distribution. Given that the observed system does not have a periodic structure, the initial distribution of crafts between nautical tourism ports does not affect the balanced state or stationary distribution of crafts in nautical tourism ports. [2]

Table 2 Transition matrix for 14 system states

\begin{tabular}{|c|c|c|c|c|c|c|c|c|c|c|c|c|c|c|}
\hline & $\mathrm{S} 1$ & $\mathrm{~S} 2$ & S3 & S4 & S5 & S6 & S7 & S8 & S9 & S10 & $\mathrm{S} 11$ & S12 & $\mathrm{S} 13$ & S14 \\
\hline $\mathrm{S} 1$ & & & 0,28 & 0,17 & 0,14 & 0,03 & 0,24 & 0,11 & & & & & 0,03 & \\
\hline $\mathrm{S} 2$ & & & 0,69 & 0,20 & 0,07 & & 0,03 & 0,02 & & & & & & \\
\hline S3 & 0,17 & 0,20 & & 0,22 & 0,14 & 0,05 & 0,16 & 0,05 & & & & & 0,01 & \\
\hline $\mathrm{S} 4$ & 0,13 & 0,08 & 0,20 & & 0,17 & 0,06 & 0,25 & 0,12 & & & & & & \\
\hline $\mathrm{S} 5$ & 0,16 & 0,05 & 0,11 & 0,26 & & 0,11 & 0,24 & 0,04 & & & & & 0,03 & \\
\hline S6 & 0,07 & & 0,22 & 0,13 & 0,20 & & 0,18 & 0,16 & & & & & 0,04 & \\
\hline S7 & 0,12 & 0,02 & 0,12 & 0,12 & 0,16 & 0,15 & & 0,22 & & & & & 0,09 & \\
\hline S8 & 0,11 & & 0,07 & 0,05 & & 0,12 & 0,27 & & 0,02 & 0,01 & 0,05 & & 0,27 & 0,01 \\
\hline S9 & & & & & & & & & & 0,48 & 0,52 & & & \\
\hline $\mathrm{S} 10$ & & & & & & & & 0,07 & & & 0,29 & 0,17 & 0,10 & 0,37 \\
\hline S11 & & & & & & & 0,07 & 0,14 & 0,09 & 0,36 & & & 0,30 & 0,04 \\
\hline $\mathrm{S} 12$ & & & & & & & & & & 0,63 & & & 0,11 & 0,26 \\
\hline $\mathrm{S} 13$ & & & & & & & 0,07 & 0,24 & & 0,16 & 0,27 & 0,04 & & 0,22 \\
\hline $\mathrm{S} 14$ & & & & & & & & & & 0,36 & 0,18 & 0,09 & 0,36 & \\
\hline
\end{tabular}

The data in Tab. 2 can be interpreted on the following assumption: if a boater is currently in the ACI Umag (S3) nautical tourism port, there is a $22 \%$ probability for that boater in the next step to sail to Marina Nautica (S4). This percentage is lower if the possibility of his next sailing to (S5) Marina Poreč is considered (14\%). The probability of boat moving from ACI Umag (S3) to Marina Vrsar (S6) in one step $n$ equals $5 \%$. According to established transition probabilities, if the boater is in ACI Umag (S3), there is a $16 \%$ probability that he will take the next step to ACI Marina Rovinj (S7). The probability that the boater will sail to ACI Pula (S8) in one step from ACI Marina Umag (S3) equals 5\% and for Y/C Mali Lošinj (S13) it is $1 \%$. For all other marinas within the nautical tourism ports system the probability of sailing from ACI Umag (S3) is $0 \%$.

Tab. 2 shows that the state of the system corresponding to (S13) Y/C Mali Lošinj is the only one with traffic communication with the ports of nautical tourism located in the Istarska County except for the ACI Pula (S8) port, which, being the nearest one, still has maintained its traffic communication with the ports of ACI Opatija (S9), Marina Punat (S10), Aci Cres (S11), ACI Supetarska Draga (S12), ACI Rab (S14) with probabilities of 0,02, 0,01, 0,05, 0,01 respectively, the leading percentage of 0,27 traffic communication referring to the port of Mali Lošinj S (13). These transition probabilities refer to the direction of crafts movement from Istrian ports to ports within the Primorskogoranska County. The S1 state corresponds to crafts entering Italian ports and thus it can be noted that these crafts are mostly sailing from Istrian ports, with the highest probability of direct departure addressing the ports of ACI Umag (S3), Marina Nautica (S4), Marina Poreč (S5), ACI Rovinj S7) with probability rates of $0,17,0,13,0,16$ and 0,24 respectively. Tab. 2 also shows that the traffic communication between Italy and the Istarska County is more intense than the communication between Italy and the Primorsko-goranska County. This is also true for the traffic communication with Slovenia, where a clear 
intensification of communication with the Istarska County can be noted through transition probabilities of $0,2,0,08$ and 0,05 respectively corresponding to the ports of ACI Umag (S3), Marina Nautica (S4) and Marina Poreč (S5). The same can be stated for the direction of craft navigation from Slovenia to Istrian ports. As far as arrivals from Italy to Istrian ports are concerned, the same marinas of ACI Umag (S3) and Marina Nautica (S4) stand out, with probability rates of 0,28 and 0,17 respectively. Moreover, the port (S7) of ACI Rovinj stands out with the probability rate of 0,24 . Within the Primorsko-goranska County, the port of Y/C Mali Lošinj (S13) is the most prominent one, with the transition probability rate of 0,03 indicating the possibility of direct flow from Italian ports. As for the crafts sailing from Slovenia to Istrian ports, a more intense traffic communication can be noted, similar to the one with Italy in the context of ACI Umag (S3), Marina Nautica (S4) with transition probability rates of 0,69 and 0,2 respectively. As for the S9 to S14 states corresponding to the ports of the Primorsko-goranska County, it is clear that there is a mutual traffic interaction that creates a hub corresponding to a bottleneck as shown in Tab. 2 in the bottom right corner. This hub communicates with the other hub located in Tab. 2 in the upper left corner and it corresponds to the traffic communication between Istrian ports. These two hubs communicate on their borderlines, via the (S7) ACI Rovinj and (S8) ACI Pula states, what makes the transition probabilities for the state between Marina Punat (S10) to the state of ACI Pula (S8) result in 0,07, from ACI Cres (S11) to ACI Pula (S8) in 0,14, and from Y/C Mali Losinj (S13) to ACI Pula (S8) in 0.24. This case also shows that Y/C Mali Lošinj (S13) communicates more intensely with the port of ACI Pula (S8) than any other port belonging to the respective hub. These transition probabilities refer to the direction of craft navigation from the Primorsko-goranska County ports to the Istarska County ports. The ACI Cres (S11) and the Mali Losinj
(S13) states have the same probabilities of direct sailing out to ACI Rovinj (S7) rated 0,07. Looking at the hub of the Primorsko-goranska County ports, then the ACI Opatija (S9) and the Marina Punat (S10) ports have maintained a more intense traffic communication with probability rates of 0,48, the ACI Opatija (S9) and ACI Cres (S11) of 0,52, and the ACI SupetarskaDraga (S12) into Marina Punat (S10) of 0,63. Intense communication was recorded in the Istrian ports hub between Slovenia and ACI Umag (S3) equaling 0,69 in the direction of craft movement from Slovenia. The transition matrix elements indicate transition probabilities not affected by the past of the process or that of the port that had been called before the craft sailed out to ACI Umag (S3), as long as the information is known regarding the name of the nautical tourism port the craft is visiting at the moment. The past of the process related to the ports previously called is now considered a superfluous piece of information.

The process of craft crossing within the nautical tourism ports network can only be in one state at each step $n$ of the process and in the next step the process may either remain in the current state or may move into the next state of the motion process. Markov chain defines transition probabilities from step to step in the process of craft crossing between different nautical tourism ports and in this accordance the transition probabilities of a craft can be determined far in advance. [2] If, for a longer period of time, a craft movement pattern follows the transition matrix shown in Table 2, then the probabilities of craft movement between nautical tourism ports become constant. Thus, the balance is reached of the observed nautical tourism ports system as shown by the stationary distribution in Table 3. In this state of balance, the largest number of crafts will enter (S7) ACI Rovinj 12\% and the lowest one (S9) ACI Opatija 1\% of the total number of crafts involved.

Table 3 Stationary distribution

\begin{tabular}{|c|c|c|c|c|c|c|c|c|c|c|c|c|c|}
\hline S1 & S2 & $\mathrm{S3}$ & S4 & $\mathrm{S} 5$ & S6 & S7 & S8 & S9 & S10 & S11 & $\mathrm{S} 12$ & S13 & S14 \\
\hline $7 \%$ & $3 \%$ & $10 \%$ & $8 \%$ & $7 \%$ & $5 \%$ & $12 \%$ & $10 \%$ & $1 \%$ & $9 \%$ & $8 \%$ & $3 \%$ & $11 \%$ & $7 \%$ \\
\hline
\end{tabular}

According to the interpretation of stationary states in Tab. 3, after a large number of sailings in and out of nautical tourism ports, $12 \%$ of crafts will call at ACI Rovinj (S7), 11\% at Y/C Mali Losinj (S13), 10\% at ACI Umag S3) and 10\% at ACI Pula (S8), 9\% at Marina Punat (S10), 8\% at Marina Nautica (S4) and 8\% at ACI Cres (S11), 7\% will be in Italy, 7\% in Marina Porec (S5), 5\% in Marina Vrsar (S6), 3\% in Slovenia (S2), 3\% in ACI SupetarskaDraga (S12) and 1\% in ACI Opatija (S9).

Tab. 3 models the distribution of the balance within the observed system based on the observed pattern of craft movement by projecting the distribution of crafts among nautical tourism ports. The results obtained are perfectly acceptable where the observed pattern of craft movement remains undisturbed. Under the influence produced upon the system by certain factors, changes occur in the crafts movement pattern, resulting in a change in the stationary distribution and balance of the system. As an example of possible impact on the system, consideration may be given to the construction of new nautical tourism ports and to the competitiveness of such ports situated in neighboring countries.

\section{CONCLUSION}

Using the Markov chain method, rules have been discovered of craft crossing within the network of nautical tourism ports in the Istarska and the Primorsko-goranska Counties, applying the newly created transition probability matrix and the calculation of the stationary vector. The transition probability matrix, as the name suggests, determines the probabilities of crossings (sailing in/out) of sports and leisure crafts (up to 20 meters) between nautical tourism ports for a single call at a nautical tourism port or for one step of the process. Furthermore, the transition matrix enables the approximation of craft crossings that have been actually taking place in the Croatian part of the Adriatic, during nautical seasons between different states of the system (nautical tourism ports).

The observed system of craft accidental movement between nautical tourism ports reaches the balance after a 
large number of $n$ steps within the process. Once a large number of craft crossings have taken place (sailing in/out) the system reaches the balance and the transition probabilities become stabilized and constant. Consequently, redistribution is achieved of a constant number of crafts within all nautical tourism ports representing the system states. Since the model has no characteristics of periodicity, the initial distribution of crafts does not affect the balanced distribution of crafts in nautical tourism ports.

Based on the research carried out, detailed information has been obtained on the areas of data dispersion and their concentration within the transition matrix corresponding to crafts crossings within the nautical ports network. A more intense traffic communication has been revealed of the Istarska County with Italy and Slovenia than with the Primorsko-goranska County. The Istria coastline being not as well indented as that in other counties, boating in the Istria County area is performed mainly along the coast. Given that the coast is more indented in the Primorskogoranska County, traffic communication operates between the coastal and island nautical tourism ports. It has been noted that the Primorsko-goranska County traffic communication with the Istarska County operates via ACI Pula (S8), Marina Punat (S10), ACI Cres (S11) and Y/C Mali Lošinj (S13). [2]

The transition matrix offers patterns of craft movement that can serve as the basis for conclusions to be made about bottleneck areas within the analyzed nautical tourism ports network in the Istarska County and the Primorskogoranska County. Based on the results of the research it can be concluded that bottlenecks are being created in similar areas that were long established in the paper by MladineoN, et al. (1988), "Decision Support System for Development of Yachting on the Adriatic Sea".

Therefore, the conducted survey has brought to light with arguments the need for nautical tourism traffic to be optimized and/or for nautical tourism routes along the Adriatic to be approximated. By detecting bottlenecks, this research can be used as the basis for further research to build upon, that should be in the function of optimizing the nautical tourism network, i.e. of planning and delivering solutions in the function of relieving the nautical tourism traffic in bottleneck areas.

\section{LIST OF ABBREVIATION}

ACI - Adriatic Croatia International Club

Y/C - Yacht Club

SYT - System of Yachting Tourism

\section{REFERENCES}

[1] Collins, L. (1975). An introduction to Markov chain analysis, London; Brothers Ltd., The Invicta Press Ashford Kent.

[2] Jadrijević, N. (2016). Model utvrđivanja konkurentnosti luka nautičkog turizma, Sveučilište u Rijeci, Pomorski fakultet, Rijeka, Doctoral Thesis, Croatian.

[3] Mladineo, N., et al. (1988). Decision Support System for development of yachting on the Adriatic Sea, Ricerca operativa, Rivista della Associazione Italiana di Ricerca Operativa, Franco Angeli, Milano.
[4] Hazelton, M. L. \& David, P. W. (2004) Computation of equilibrium distributions of Markov traffic-assignment models. Transportation Science, 38(3), 331-342. https://doi.org/10.1287/trsc.1030.0052

[5] Hu, J. \& Prandini, M. (2003). Aircraft conflict detection: a method for computing the probability of conflict based on Markov chain approximation. European Control Conference, Cambridge, UK, IEEE. https://doi.org/10.23919/ECC.2003.7085297

[6] Philpott, A. \& Mason, A. (2001). Optimising Yacht Routes under Uncertainty. $15^{\text {th }}$ Chesapeake Sailing Yacht Symposium, Annapolis, USA.

[7] Bertsekas, D. P. \& Tsitsiklis, J. N. (2000). Introduction to Probability, Institute of Technology Cambridge, Massachusetts, Chap. 6; Lecture notes. Available from: http://faculty.pucit.edu.pk/faisal/ma249/book.pdf

[8] Jadrijević, N., Kolanović, I., \& Stanivuk, T. (2017). Charter and Nautical Service Quality in Function of Nautical Tourism Port Competitiveness. $7^{\text {th }}$ International Maritime Science Conference - IMSC Solin, Croatia.

[9] Strategija razvoja nautičkog turizma Republike Hrvatske za razdoblje 2009. - 2019. (2008). Ministarstvo mora, prometa $\mathrm{i}$ infrasrukture/Ministarstvo turizma, Croatian.

[10] Perko, N., Stupalo, V., \& Jolić, N. (2011). Impact of nautical crafts on Croatian sea ports capacity. $14^{\text {th }}$ International Conference on Transport Science - ICTS, Portorož, Slovenia.

\section{Contact information:}

Ines KOLANOVIĆ, PhD, Associate Professor

(Corresponding author)

Faculty of maritime studies Rijeka

Studentska 2, 51000 Rijeka, Croatia

E-mail: ines@pfri.hr

Nela JADRIJEVIĆ, PhD

Trg hrvatske bratske zajednice 1

21000 Split

Tanja POLETAN JUGOVIĆ, PhD, Full Professor

Faculty of maritime studies Rijeka

Studentska 2, 51000 Rijeka, Croatia

E-mail: poletan@pfri.hr 